\title{
RESONATION OF THE VITRUVIUS'S MODULAR, SYSTEMATIC APPROACH WITH THE COMPUTATIONAL MINDSET OF THE DIGITAL AGE: 3D MODELING OF THE IONIAN TEMPLES OF AEGEAN TURKEY
}

\author{
A. Denker ${ }^{1,2}$ \\ ${ }^{1}$ Istanbul Bilgi University, 34060 Eyup, Istanbul, Turkey \\ ahmet.denker@bilgi.edu.tr \\ ${ }^{2}$ Near East University, Mersin 10, Turkey \\ ahmet.denker@neu.edu.tr
}

Commission II, WG II/8

KEY WORDS: Temples of Ionia, dipteral temples, pseudo-dipteral temples, reconstructing the past, virtual reality.

\begin{abstract}
:
Eight of the greatest Ionic temples of the ancient world were built on or near the Aegean coast of Turkey, from the dipteros of Chersiphron in Ephesos to the pseudo-dipteroi of Hermogenes in Teos and Magnesia. The temples were the epitome of elegance and splendour, difficult to surpass in terms of architectural achievement for a period of four centuries from $6^{\text {th }}$ century to $2^{\text {nd }}$ century $\mathrm{BC}$ which spans Archaic, Classical and Hellenistic eras. All of these edifices now lie in ruins. As various empires in the region rose and fell, the temples suffered looting and destruction. Nature also played a part with rivers inundating the temenoses and silting up the archaeological remains, and earthquakes toppling columns and reducing the cellas to rubble. Despite this catacylism, tens of hundreds of years after they were built, these marble buildings still tantalise the human imagination. The objective of this paper is to present a systematic and comprehensive treatise of the logical procedure of the $3 \mathrm{D}$ visualisation of these monuments of the ancient cities of classical antiquity. The virtual rediscovery and visual recovery can never replace or remedy the loss of the temples. It can, however, visually awaken the imagination and provide a hypothesised experience of the temples as well as restoring a sense of the architecture and the place.
\end{abstract}

\section{INTRODUCTION}

\subsection{Ionian Eight}

The Ionian order of architecture reached its peak with the construction of eight large Ionian temples on the east coast of Aegean. They were the fruits of the Ionian temple-building era. This era was started with the construction of the Artemis Temple in Ephesus in the first half of the $6^{\text {th }}$ century BC and ended with the Temple of Dionysos in Teos at the end of the $2^{\text {nd }}$ century BC (Akurgal, 2011).

The eight large Ionian temples, 'Ionian Eight', had ruled in the same geographical region (Figure 1). Five of these were built on or near the Aegean coast of Asia Minor. The remaining three were in their immediate hinterland, separated by surmountable distances from the others. Together, they displayed elegance and supremacy that was not to be surpassed in any other region of the antique world by architectural achievements. These are the Temple of Artemis in Ephesus, the Temple of Apollo in Didyma, the Temple of Athena Polias in Priene, the Temple of Artemis in Sardis, the Temple of Artemis Leukophryene in Magnesia, the Temple of Aphrodite in Aphrodisias, the Temple of Dionysus in Teos, the Temple of Apollo at Smintheion (Figure 2). Pioneer temples of the Ionic order were built in the Archaic age, when the Greek Ionians were at the height of their golden era, followed by others in the Classical and Hellenistic periods. Of these most important sanctuaries in the Aegean Turkey, only the foundations made of limestone with some fragments of the marble structure remained at their original location. The superstructures, courts and steps of the temples had already been looted to a lamentable extent. The superstructures had collapsed and the remnants of them came down to us as ruined sites, a few rare extant columns, flattened cellas and sets of broken fragments. Our understanding of how they might have looked depended basically upon what the ancient authors such as Pliny (Pliny, Natural History) and Vitruvius (Vitruvius, De Arhitectura) said about them, as well as several more recent explorers and authors. With temples so significant as the eight Ionian monuments presented here, the list of the authors who wrote in this field is necessarily extensive.

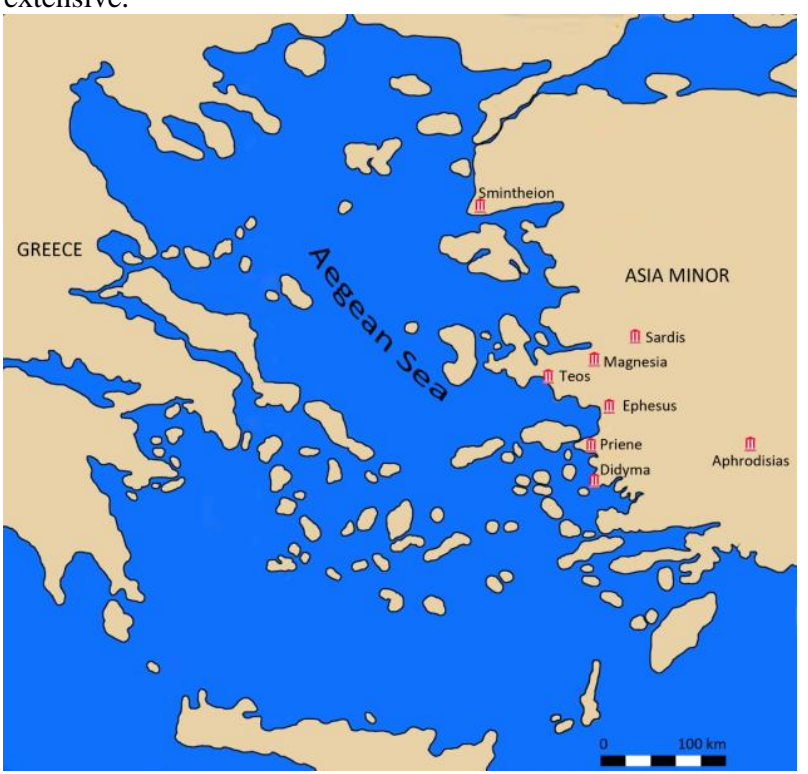

Figure 1. Ionian Eight 


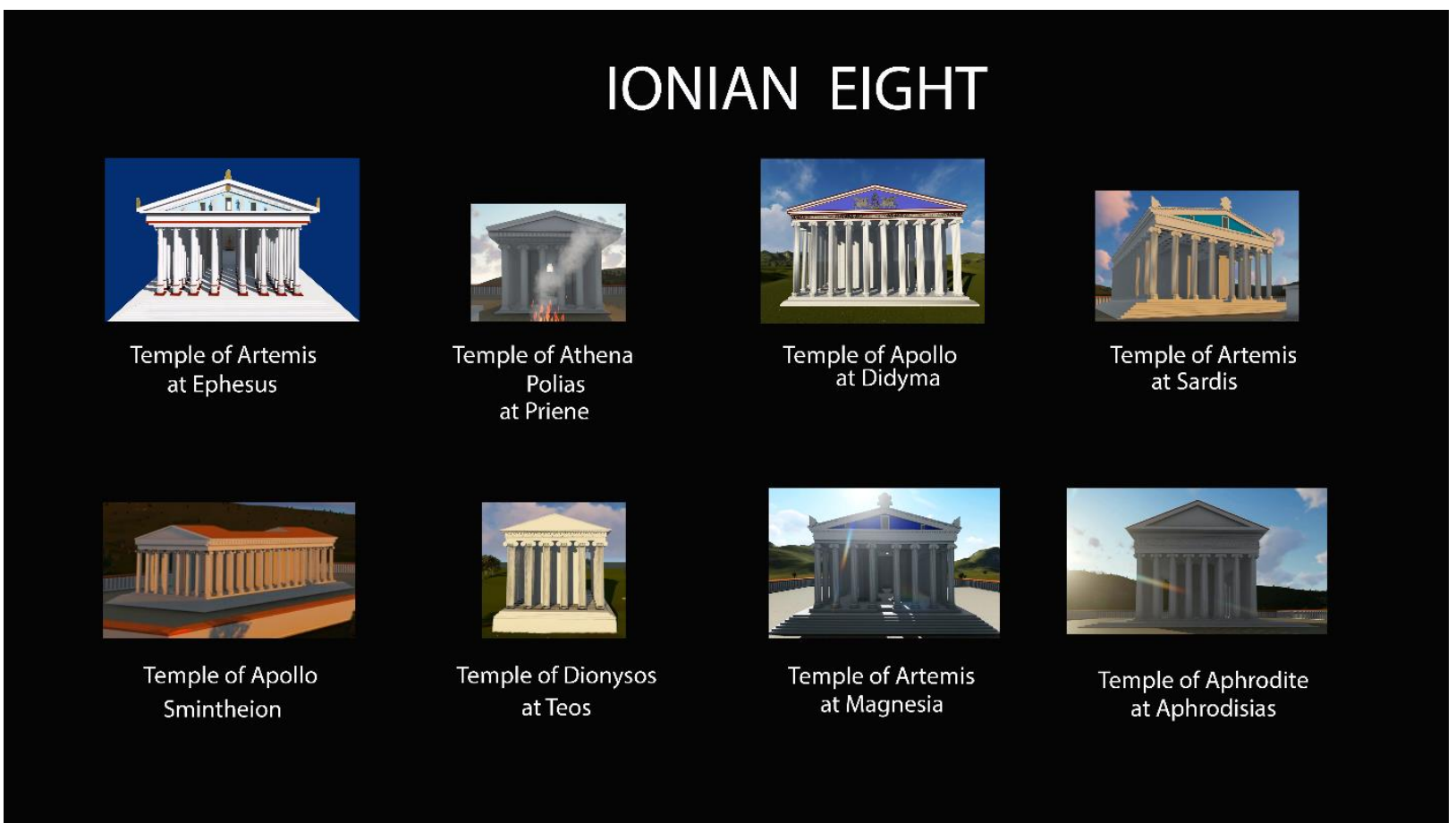

Figure 2. Ionian Eight

In this article, specific mention is made of those who had dedicated their lives and careers to discovering and unearthing the particular parts and pieces of these temples, for example one cannot propound suggestions about the reconstruction of the Temple of Artemis at Ephesus without mentioning the name of John T. Wood, or about the Temple of Artemis Leukophryene in Magnesia without reference to the works of Carl Humann (Humann, 1904) and O. Bingol (Bingol, 2007). The virtual reconstruction of the original temples constituted a challenging task and called for an integrated approach to the subject. This is attempted by re-examining central issues and design theories of Ionic temples in light of recent archaeological survey results and with the advent of advances in computer graphics technologies. While the archaeological remains provided some evidence, missing elements required the development of reconstruction hypotheses based on architectural similarities between the various Temples of Ionia. This approach calls for constructive synthesis of designs developed by a range of architects from Theodorus in $6^{\text {th }}$ century BC to Hermogenes in $2^{\text {nd }}$ century $\mathrm{BC}$. The virtual rediscovery and visual recovery can never replace or remedy the loss of the temples. It can, however, visually awaken the imagination and provide a hypothesised experience of the temples as well as restoring a sense of the architecture and the place.

\subsection{The Impetus}

The impetus to exploit Computer-based 3D reconstruction and virtual reality technology in the cultural heritage domain of 'Ionian Eight' aims at reaching the goals which are organized around the following three schemes:

1. The 3D reconstruction of each of the lost Ionic Temples of Aegean Turkey in as close form to their original as possible.

2. The placement of the individual models within the recontextualized $3 \mathrm{D}$ environment.
3. Piecing together the individual $3 \mathrm{D}$ models and the $3 \mathrm{D}$ environment to establish a comprehensive virtual representation of the whole set of 'Ionian Eight'.

This approach has even been made explicit in literature (Denker, 2017) as a way of ensuring conservation of cultural heritage and enhancement of accessibility and awareness. It enables physically inaccessible cultural heritage digitally reachable

\section{METHODOLOGY OF VIRTUAL 3D RECONSTRUCTION}

All these temples had ended up as quarries. When the data is missing and architectural elements are destroyed due to ravages of time and humankind, other sources are sought for filling the missing information.

Ionic Temple Architecture, in fact, can be resembled to a system of formal relations where the rules for its design (e.g. rhythm, symmetry, proportions) and construction are defined to a large extent (Tzonis, Lefebvre, 1999). Drawing much of his aesthetic theory from earlier Greek sources, Vitruvius propounded the line of thought that harmony and beauty followed from ratios of small whole numbers, though not in a very coherent way, in his famous De Architectura. He put forward that there should be 'a correspondence among the members of an entire building, and of the whole to a certain part selected as standard.' He then proceeded to postulate that the ratios governing the dimensions of a building should be derived from a basic module. Vitruvius's modular, systematic approach resonates with the computational mindset of the digital age (Seldana, 2015). Digital modelling requires evident traits and characteristics in order to create a successful and versatile procedure. However, talking about the problems of applying Vitruvian theory in the field, W. Jones stated that such a regularity rarely occurs in practice (Jones, 2009). It is inevitable that the virtual 
reconstructions will contain some uncertainty and some hypothetical elements. The inherent uncertainty and the degree of hypothetical elements can be minimized by giving these eight Ionian temples a formal and holistic approach. Prescribed operation of virtual 3D reconstruction requires structured and uniform data.

In the problem of reconstructing the Ionian Temples of Aegean Turkey there exist vast amount of scattered and unstructured data, we needed to use them to spot connections and patterns between these temples in hopes of gaining insight into their common features.

Holistic modelling of the 'Ionian Eight' is predicated on the assumption that provided the sources for the model can be effectively managed and documented, there are substantive benefits to be derived from linking each modelling element in accordance with its context within the 'Ionian Eight' as a whole. This helps in testing the informed hypotheses that are worth making in order to fill the lacunae of information.

This holistic approach is based on the following underlying procedures.

\subsection{Tracing Their History}

In order to collate information about these edifices their construction, reconstruction and destruction had been traced with attention to their architecture and architects. Exceptional architects who had developed the style and construction principles are studied.

\subsection{Building a corpus of information}

Compilation of the corpus was based on information gathered about the activities comprising of excavations and surveys, as well as documents including ancient and more recent texts, excavation and survey reports, architectural sketches and drawings. The superstructures created by exceptional master builders are examined through the accounts of ancient and more recent writers, fragments in museums, and surviving remnants.

\subsection{Empirical Data}

It is impossible to fully understand these temples through the veil of corpus in 2.2. They can be properly studied only by travelling to their sites and by paying visits to the European Museums which keep the major fragments of them in their collections.

Travelling from one temple site to the other or passing from one museum room to the other, the author tried to understand the unique identity of their architecture and explore the connections that once linked them.

\subsection{Curating the content}

A significant issue for reconstruction is managing the avalanche of data, and vast list of writings. Combining evidence from ancient texts, empirical archaeological data, and geographical landscape surveys proves to be an arduous undertaking. Subsequent to the collation of primary and secondary source material, focus is shifted from one of knowledge compilation to one of knowledge curation.

How the content curation is done from compiled data to temple attributes is depicted in Figure 3 which shows how information is selected, processed and what is considered to be of importance for the virtual 3D reconstruction (Apollonia, 2013).

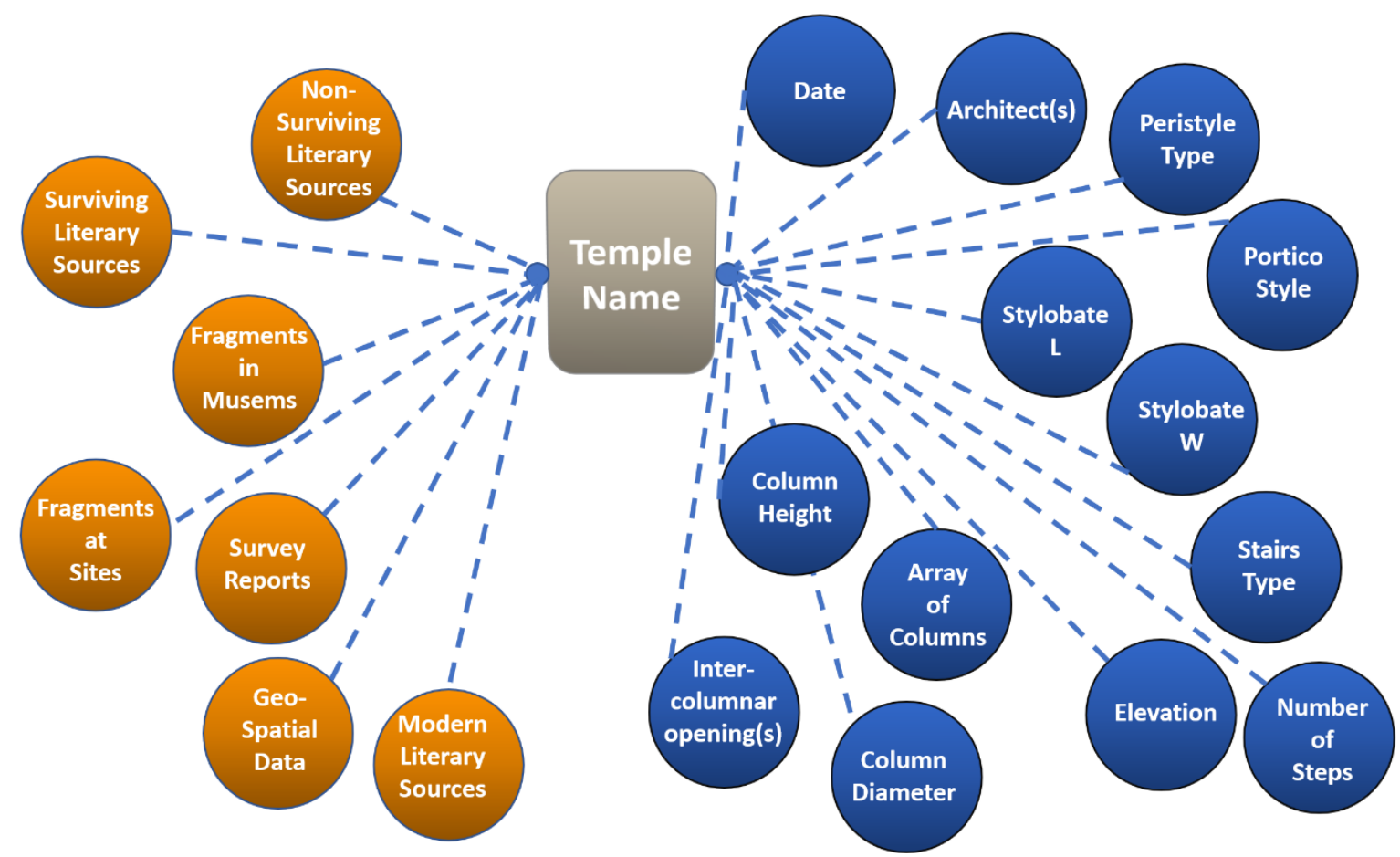

Figure 3. Curating the content: From compiled data to temple attributes 


\subsection{Putting it All Together}

When all the data about the 'Ionian Eight' are put together it is intriguing to observe that these temples are governed by well determined set of rules pertaining to a) orderly arrangement of architectural elements b) rhythm and proportionality c) symmetry. Temple attributes of 'Ionian Eight' are presented in Table 1.
Eight' virtual reconstruction project. Autodesk AutoCAD ${ }^{\circledR}$ was employed for $2 \mathrm{D}$ drawings of plans and elevations. The software used for the 3D reconstruction of Ionian Temples was Autodesk 3ds Max®. Lumion ${ }^{\circledR}$ was implemented for construction of the environment. As an example, the 3D modeling phases of a temple and its final appearance is presented in Figure 4.

\begin{tabular}{|c|c|c|c|c|c|c|c|c|}
\hline $\begin{array}{l}\text { Temple } \\
\text { Attributes }\end{array}$ & $\begin{array}{l}\text { Temple of } \\
\text { Artemis } \\
\text { Leukophryne } \\
\text { (Case Study) }\end{array}$ & $\begin{array}{l}\text { New Temple } \\
\text { of Artemis } \\
\text { at Ephesus } \\
\text { (Classical) }\end{array}$ & $\begin{array}{l}\text { Temple of } \\
\text { Athena } \\
\text { Polias at } \\
\text { Priene }\end{array}$ & $\begin{array}{l}\text { New } \\
\text { Temple of } \\
\text { Apollo at } \\
\text { Didyma }\end{array}$ & $\begin{array}{l}\text { Temple of } \\
\text { Artemis at } \\
\text { Sardis }\end{array}$ & $\begin{array}{l}\text { Smintheion } \\
\text { in Troas }\end{array}$ & $\begin{array}{l}\text { Temple of } \\
\text { Dionysos at } \\
\text { Teos }\end{array}$ & $\begin{array}{l}\text { Temple of } \\
\text { Aphrodite } \\
\text { at } \\
\text { Aphrodisias }\end{array}$ \\
\hline Date & $220 \mathrm{BC}$ & $356 \mathrm{BC}$ & 345 BC & $333 \mathrm{BC}$ & $300-275 \mathrm{BC}$ & $\begin{array}{r}\text { Mid } 3^{\text {rd }} \\
\text { Century } \\
\text { B.C. }\end{array}$ & $190 \mathrm{BC}$ & $\begin{array}{r}\text { Late } 1^{\text {st }} \\
\text { Century } \\
\text { B.C. }\end{array}$ \\
\hline Architect(s) & Hermogenes & Cheriokrates & Paeonius & Paeonius & $?$ & $?$ & Hermogenes & ? \\
\hline $\begin{array}{l}\text { Peristyle } \\
\text { type }\end{array}$ & $\begin{array}{l}\text { Pseudo- } \\
\text { dipteral }\end{array}$ & Dipteral & Peripheral & Dipteral & $\begin{array}{l}\text { Pseudo- } \\
\text { dipteral }\end{array}$ & $\begin{array}{l}\text { Pseudo- } \\
\text { dipteral }\end{array}$ & Peripheral & $\begin{array}{l}\text { Pseudo- } \\
\text { dipteral }\end{array}$ \\
\hline $\begin{array}{l}\text { Portico } \\
\text { Style }\end{array}$ & Octastyle & Octastyle & Hexasytle & Decastyle & Octastyle & Octastyle & Hexastyle & Octastyle \\
\hline Stylobate L & $57.89 \mathrm{~m}$ & $111.48 \mathrm{~m}$ & $37.17 \mathrm{~m}$ & $111.55 \mathrm{~m}$ & $97.94 \mathrm{~m}$ & $47.88 \mathrm{~m}$ & $19.9 \mathrm{~m}$ & $8.5 \mathrm{~m}$ \\
\hline $\begin{array}{l}\text { Stylobate } \\
\text { W }\end{array}$ & $31.6 \mathrm{~m}$ & $51.44 \mathrm{~m}$ & $19.53 \mathrm{~m}$ & $49.6 \mathrm{~m}$ & $45.51 \mathrm{~m}$ & $30.82 \mathrm{~m}$ & $32.57 \mathrm{~m}$ & $31 \mathrm{~m}$ \\
\hline Stairs type & All sides & All sides & All sides & All sides & All sides & All sides & All sides & All sides \\
\hline $\begin{array}{l}\text { Number of } \\
\text { steps }\end{array}$ & 7 & 10 & 3 & 14 & 6 & 10 & $\begin{array}{r}11 \text { (front) } \\
5 \text { (sides) }\end{array}$ & 4 \\
\hline $\begin{array}{l}\text { Column } \\
\text { Height }\end{array}$ & $13.10 \mathrm{~m}$ & $17.65 \mathrm{~m}$ & $11.40 \mathrm{~m}$ & $19.5 \mathrm{~m}$ & $17.8 \mathrm{~m}$ & $10.096 \mathrm{~m}$ & $8.806 \mathrm{~m}$ & $9.288 \mathrm{~m}$ \\
\hline $\begin{array}{l}\text { Array of } \\
\text { Columns }\end{array}$ & $8 \times 15$ & $8 \times 27$ & $6 \times 11$ & $10 \times 21$ & $8 \times 20$ & $8 \times 14$ & $6 \times 11$ & $8 \times 13$ \\
\hline $\begin{array}{l}\text { Column } \\
\text { Diameter }\end{array}$ & $1.485 \mathrm{~m}$ & $1.840 \mathrm{~m}$ & 1.425 & $2.022 \mathrm{~m}$ & $2.094 \mathrm{~m}$ & $1.289 \mathrm{~m}$ & $1.036 \mathrm{~m}$ & $2.176 \mathrm{~m}$ \\
\hline
\end{tabular}

Table 1 Temple Attributes

This table shows that architectural proportions do not follow norm values but vary with every building. The variance of proportions in these buildings of equal beauty implies that the designers of them freely reigned their creativity and inventiveness. Nevertheless, despite differences in details and numerical values of the ratios, the logic behind the recipes of Vitruvius remains valid and gives guidance throughout reconstructions.

\subsection{D Modelling}

Digital tools provide a means of aligning architectural, and quantitative information summarized in Table 2 with textual, textural and geographic information. There are several stages of digital reconstruction of an ancient temple and its site. These include 2D drawing of antique monuments in comparative dimensions; placing them in relative positions and orientations on the geo-spatial plan which represents the topography and natural landscape; creating 3D graphical elements with surfaces composed of a number of polygons. These surfaces are given photorealistic appearance through the use of appropriate texture maps and lighting. The placement of the light sources which generate the solar illumination and shadow effects in Aegean Turkey were imperative for creating the right atmosphere. When rendered the reconstructed $3 \mathrm{D}$ virtual objects exhibit the 'Ionian

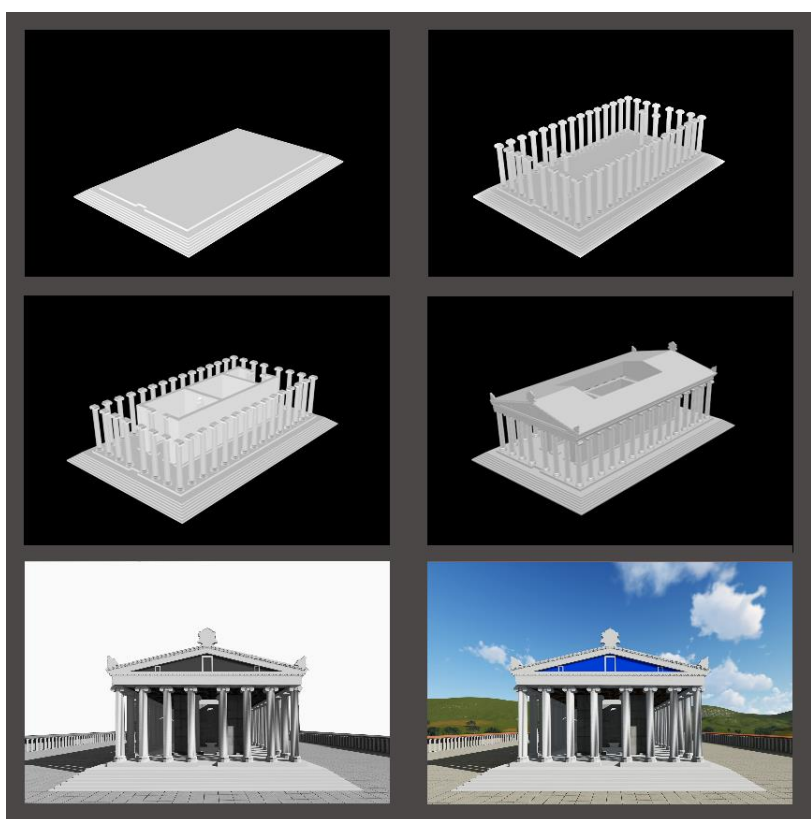

Figure 4. 3D modeling phases of a temple 
In the following section The Temple of Artemis Leukophyrne at Magnesia is treated as a case study to illustrate the methodology of virtual 3D reconstruction.

\section{CASE STUDY: THE TEMPLE OF ARTEMIS LEUKOPHRYNE AT MAGNESIA}

The question of how one does reconstruct an entire structure from archaeological texts, extant fragments and other artefacts is addressed by focussing as a case study on the digital reconstruction of the Temple of Artemis Leukophryene in Magnesia. The reason that this particular temple is selected as the case study to illustrate the method of digital reconstruction is because it is considered by the author the most 'secure' of the 8 reconstructions presented here, thanks to the large number of extant pieces in situ, as well as fragments in museums like Museum of Pergamon and works of Humann and Bingol.

Hermogenes who lived at the end of the $3^{\text {rd }}$ and the beginning of the $2^{\text {nd }}$ centuries B.C. was one of the most important architects of Ionic style; he exploited the regular proportions and other rational properties of the Priene Temple's design. In Hermogenes' design the ground plan is divided by equidistant horizontal and vertical lines into a rectangular grid (Vitruvius, De Architectura). The grid partitions the stylobate and fixes the positions of architectural elements (Figure 5)

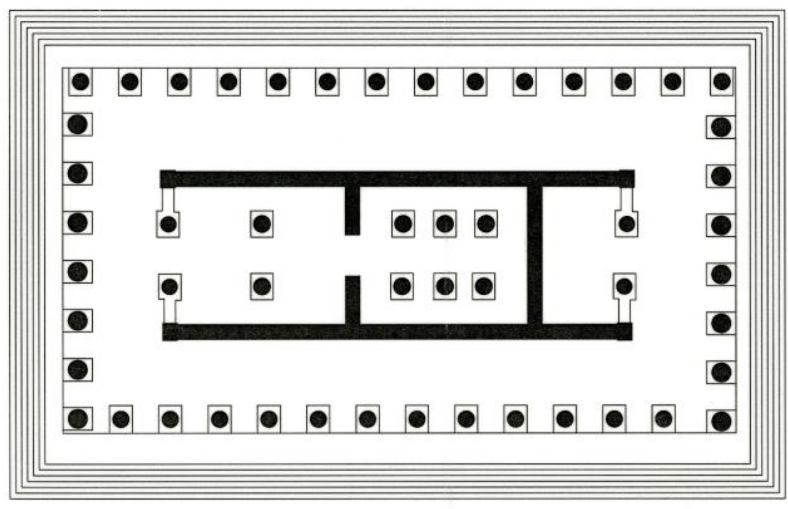

Figure 5. Ground plan of the temple of Artemis Leukophyrene at Magnesia.

Once the ground plan which is sectioned and sub-sectioned by the grid system is laid then it is ready to be populated by the architectural elements such as peripheral columns and walls of cella. With Hermogenes' design of the Temple of Artemis Leukophryne at Magnesia, the simple harmony of pseudodipteral design was firmly established (Humann, 1904). The columns were equally spaced, pinned at the nodes of a large grid and aligned with the cella walls. This made the ground plan resemble a draught's board. It was a pseudo-dipteral temple; octastyle façade was retained but the inner colonnade was omitted (Bingol, 2007). He achieved this without reducing the temple's beauty and attractiveness (Jenkins, 2006). In fact, the resulting effect was the opposite, the encircling peristyle was enlarged to a width of 2 axials, and the heavy mass of columns at the entrance was contrasted with an avenue space at the peristyle, thereby making it more 'user friendly' (Figure 6) (Humann, 1904) and (Bingol, 2007).

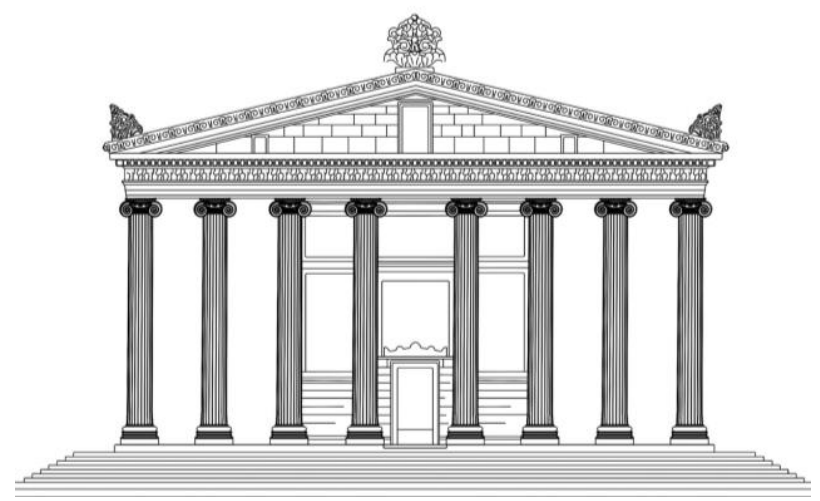

Figure 6. Front elevation of the Temple of Artemis Leukophryne at Magnesia (Adaption after Humann)

The conceptual principles introduced by Hermogenes in the Ionian temple architecture were set out in a book written by Hermogenes himself in the $2^{\text {nd }}$ century BC. The architects of the Hellenistic and Roman periods adopted and applied his theories; so Hermogenes has affected not only the architecture of antiquity, but also that of the Renaissance. Regrettably, Hermogenes' book has not survived, but was known to Vitruvius whose own book borrowed a great deal from that book.

The columns were tapped with ionic capitals. Their exact heights are not known, since not a single one has survived, the height is estimated to be $12 \mathrm{~m}$. Its western pediment has been reconstructed from the surviving fragments. It shares common features with the Ephesian Artemision. They both have big windows in the middle of the pediment flanked by two smaller windows on both sides.

The Temple of Artemis Leukophryene in Magnesia comes down to us as a set of broken fragments. It is not possible to make an accurate reconstruction of the temple without visiting the Pergamon Museum and the Ruins. Some of the rare surviving fragments, including capitals of the temple are now in Pergamon Museum. Among the fragments are some of the surviving examples of the finest form of the Ionic capitals. The advanced masonary technique of the Magnesian masters gave the Ionic capital its final distinctive form. This form was first established at Ephesus and was later followed in Didyma and Sardis, and perfected in Magnesia.

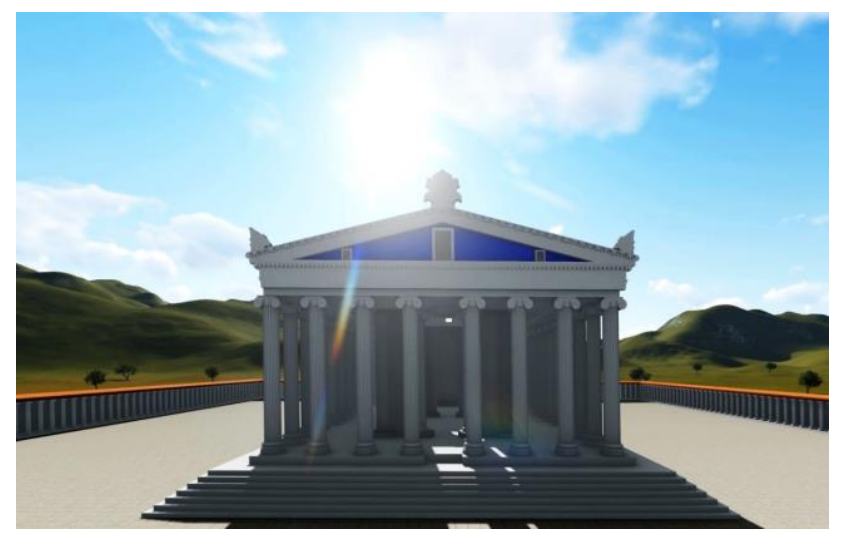

Figure 7. The Reconstruction of the Temple of Artemis Leukophryne at Magnesia. 
Axially in front of the temple stands an altar. Temple and Altar both faced west. The reconstructed temple (Figure 7) was adorned with rich colour; colour had been an integral part of temple building in Ionia (Vinzenz, 2010). The likely reason may have been to make the building more visible and enticing to the visitors from afar.

\subsection{The First of the Great Dipteral Temples: The Temple of Artemis at Ephesus}

The earliest of the Ionian Eight was the Temple of Artemis in Ephesus (The Artemision). It was a colossal marble temple built around the middle of the $6^{\text {th }}$ century B.C. (ca. 550 B.C.). It was first dipteral temple that is why it is also called Dipteral 1. Dipteral 1 was burned the night Alexander was born (356 BC) (Jenkins, 2006), once again to be built (356 BC) with more splendour and magnificence (Classical Artemision).

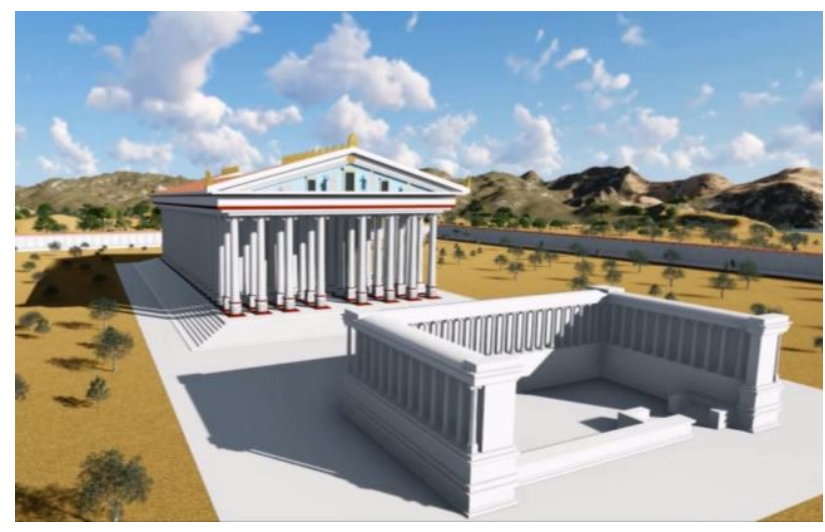

Figure 8. Reconstructed Classical Artemision

It was revered as one of the Seven Wonders of the World. This temple which Pliny calls the 'universum templum' was destroyed by invading Goths in 262 A.D. and was never rebuilt (Bammer, 1984). The site of the temple now is barren with only one standing column, its reconstructed image is given in Figure 8.

\subsection{The Only Peripheral Temple of the Aegean Turkey:} The Temple of Athena Polias at Priene

The Temple of Athena Polias was arguably the most picturesquely situated of all the temples of Aegean Turkey. It was perched on a natural shelf below the towering cliffs of Mount Mycale with a commanding view over the valley below.

The commencement of the temple which Prieneans started to build to the honour of Athena Polias, the goddess of the city, dates to $345 \mathrm{BC}$ (Ferla, 2006). This temple has a significant profile in classical architecture. One reason for its importance is that it was the masterpiece of Pytheos who undertook the design and construction of this temple around $350 \mathrm{BC}$, he supervised the construction until $330 \mathrm{BC}$. With this temple he broke new ground, as it is the only peripteral sanctuary of Aegean Turkey. Pytheos attempted to develop the temple building and Ionic order, from its $6^{\text {th }}$ century roots, as much in its proportions as in style.

The Temple of Athena Polias was built out of white marble. Its columns were laid out on a mathematical grid of squares. Today from its columns only five ones remain erect, alongside a 3-step crepidoma. Figure 9 shows its reconstruction.

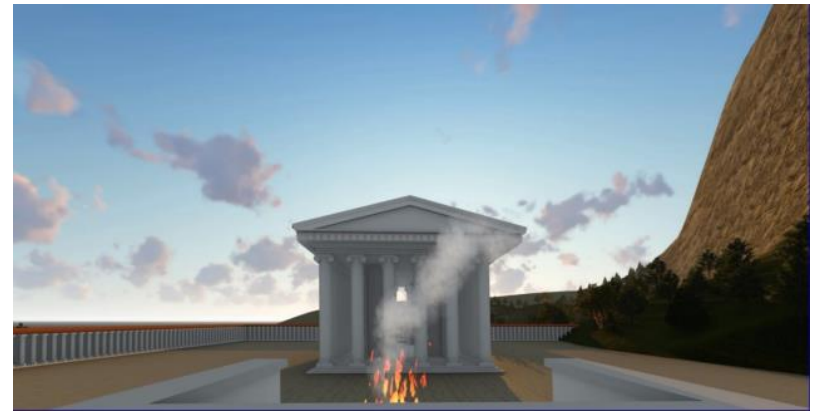

Figure 9. Reconstruction of the Temple Athena Polias at Priene.

\subsection{The Only Decastyle Temple of Aegean Turkey: The Temple of Apollo at Didyma}

The Dipteral Temple of Apollo at Didyma (Didymaion) has a special importance for the continuation and development of Ionic architecture style in Aegean Turkey (Gruben, 1963). Paeonius, the architect of the classical temple in Ephesus was also the architect of the temple in Didyma. From this temple enough remains have been preserved to secure its reconstruction. It stands out as the most impressive ruin of the Aegean Turkey. There still stand tall and erect the only three columns with their Ionic capitals along the whole coast of Aegean Turkey. They constitute the only trio which have been spared destruction by human hand or nature. The design of this temple was determined by features adopted from the temples of Ephesus and Priene. The first feature was a high crepidoma with a flight of 14 steps at the front side. This feature was carried over from the Artemision by Paeonius. The second feature was applied by Pytheos in Priene at Temple of Athena Polias. It served as a model in Didymaion. Columns were organised according to a system of axes and underpinned at the nodes of a huge rectangular grid. The building of this grand temple continued until the middle of the $2^{\text {nd }}$ century $\mathrm{AD}$, but never finished. We tried to visualise the grandiose of the finished temple in Figure 10.

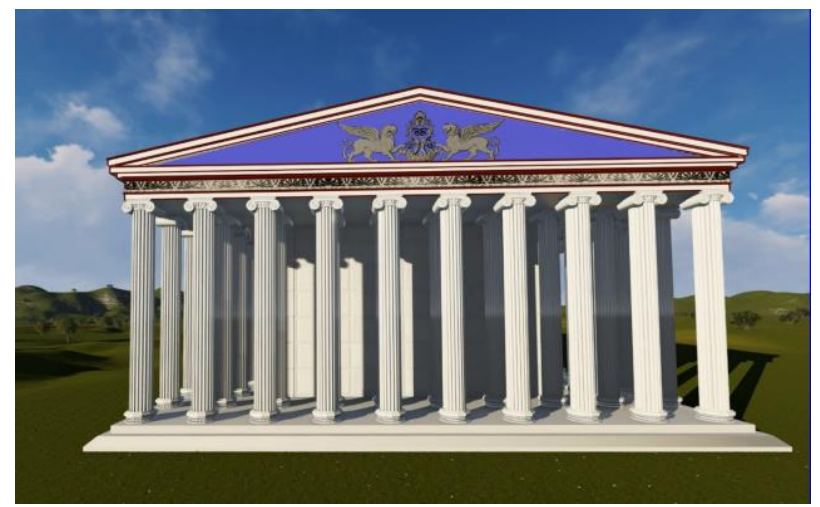

Figure 10. 3D Visualisation of the grandiose of the finished Didymaion.

\subsection{The First Pseudo-Dipteral Temple of Aegean Turkey: Temple of Artemis at Sardis}

The third of the great Ionic temples of Aegean Turkey is the Temple of Artemis at Sardis. It is the second of the greatest Ionic temples after Didymaion that has survived to day. Thanks to its well-preserved details, its reconstruction can be made with 
reasonable certainty. Two of the columns are still standing with their capitals. One of the architrave blocks survived as a whole. Three more capitals were discovered during the excavations of Butler which were published in two volumes (Butler, 1922a) and (Butler, 1922b). With large volutes and egg-and-tongue on the echinus, they reflect the classical and even archaic traces of style. The design exhibited a marked resemblance to Archaic Artemision (Yegül, 2012). Although in its size and outer appearance it resembles the other two great dipteroi, it differs from them fundamentally. Despite appearing from both ends to adhere faithfully to the traditional dipteros scheme, it had no inner colonnades on the flanks.

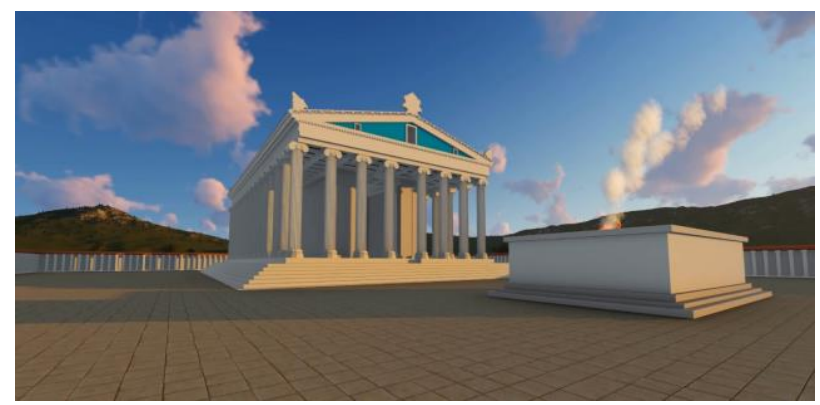

Figure 11. Reconstruction of the Temple of Artemis at Sardis

\subsection{The Temple of Apollo Smintheon at Troas}

This Temple is located in the northernmost location of all the Ionic Temples of Aegean Turkey. It is an early example (Mid. $3^{\text {rd }}$ century $\mathrm{BC}$ ) of pseudo-dipteral temples and can be considered as antedating the temples of Hermogenes. It may have influenced the great architect Hermogenes. This temple was octastyle pseudo-dipteral with fourteen columns on the flanks (Özgünel, 2011). Hermogenes designed two temples of this style at Teos (190 BC) and Magnesia (220 BC).

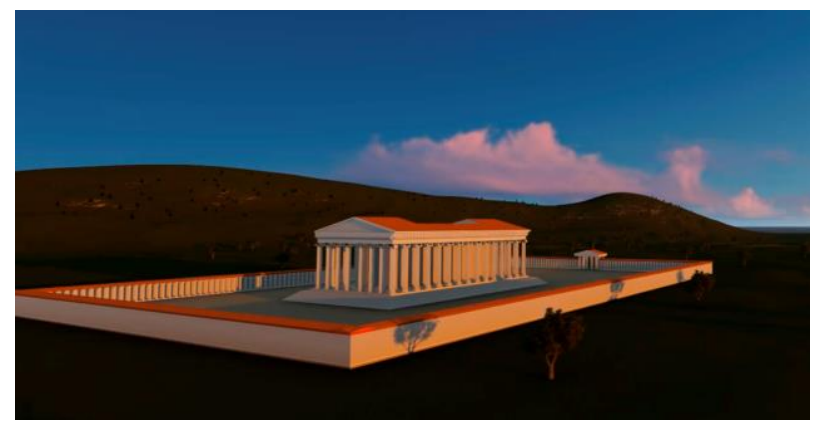

Figure 12. Reconstruction of the Temple of Apollo Smintheion at Troas

\subsection{The Temple of Dionysos at Teos}

Teos is an ancient Ionian city which is claimed to be Dionysos' birthplace. Its temple inside the city walls was the first celebrated work of Hermogenes. This is the second mention of architect Hermogenes, we had met him above when we visited the Temple of Artemis Leukophryne at Magnesia.This temple was designated by Vitruvius as an example of the 'beautifulcolumned' proportions of Hermogenes. The arrangements are very similar to Priene, showing the influence of Pytheos on Hermogenes. The temple was built on a slanting ground and sat on a rock-cut podium. It is the smallest of the Ionic temples of Aegean Turkey. It is hexastyle and peripteral with eleven columns on the flanks (Dinsmoor, 1950).

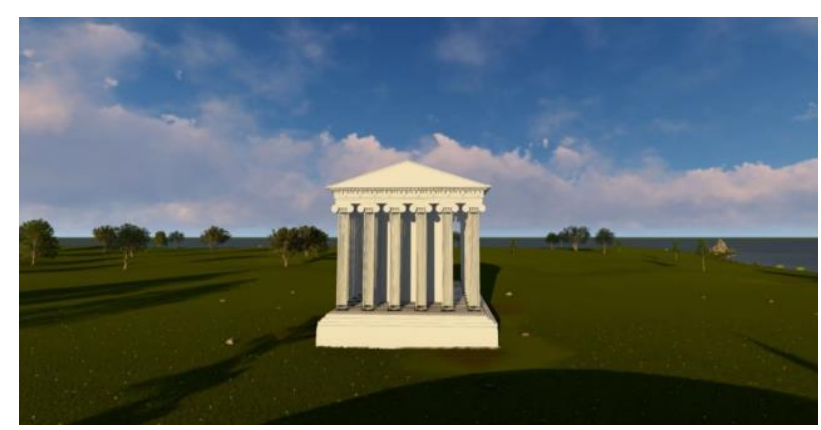

Figure 13. Reconstruction of the Temple of Dionysos at Teos

\subsection{The Temple of Aphrodite at Aphrodite at Aphrodisias}

Carians founded the city of Aphrodisias in $2^{\text {nd }}$ century B.C. and it flourished under Roman rule. Aphrodite was the chief deity to whom a marble temple was erected. The temple was located in the northern half of the city, and was the focal point of the city in antiquity. It was an octastyle building with thirteen columns on the sites. With its fourteen standing columns it is still one of the most impressive ruins of Aegean Turkey.

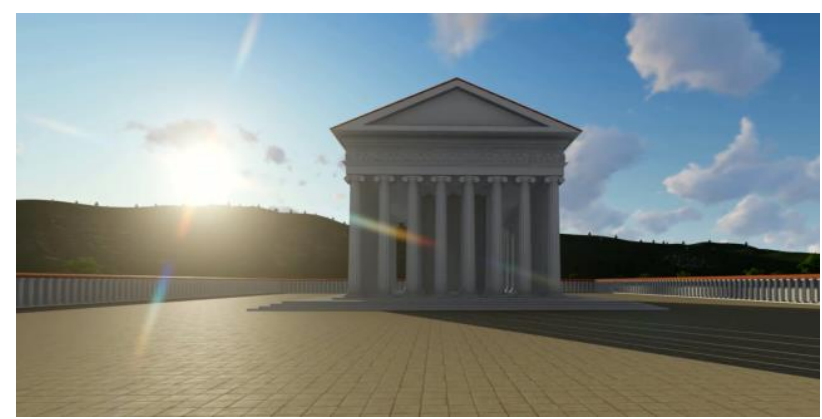

Figure 14. The Reconstruction of the Temple of Aphrodite at Aphrodisias.

\section{CONCLUSIONS}

The virtual reality application presented here is driven by a specific cultural heritage problem: Making the eight lost Ionian temples visible in digital space as they were in their heydays when no other building could compare with them in splendour. 'Ionian Eight' provide the researchers with a clear picture of architecture in ancient Ionian cities of the late Archaic, Classical and early Hellenistic periods. The dipteros which was designed by the pioneering architects of the Temple of Artemis at Ephesus presented a 'fairy-tale' splendour to the beholder with its early Ionic 'forest of columns' (Gruben, 2001). However, it became obvious during the ensuing centuries that there was no more interest in constructing temples like those. So much could not be spent on sanctuary buildings any more.

The answer to this paradigm shift was given by new pioneering architects in later temples. In complete contrast to the original idea of the 'forest of columns' of dipteroi, they broke new ground thereby giving more space and looseness to the Ionic temple design. Porticoes and pteromata have been widened to two inter-axials by removing the inner colonnade. Hidden behind the façade of the dipteros, pseudo-dipteros tied the bonds of the archaic temple building tradition with the renaissance of temple building in Ionia. From the ancient texts we learn that the beholders used to share a sense of wonder with the sights of the Temples of Ionia. It seems that this response 
was the consequence of an acquired taste, originating from the cultural and aesthetic values established at a certain epoch of history in a particular geographical location. These temples will never stand again. A few lonely columns remained standing in their sites, a top of them now stork's nests. They are the forlorn remainders the 'forest of columns' there once were. The sanctuaries of Artemis, Apollo, Aphrodite, and Dionysos are gone forever. The sculptures of the deities now dwell in the prominent museums of the world. This lost feat of architecture has been revived in this paper, through the $3 \mathrm{D}$ reconstruction of the dipteria and pseudo-dipteria of Aegean Turkey. The 3D reconstruction models in this article are the reconstruction of temples that are neither in full existence nor completely documented; therefore it is inevitable that these reconstructions are complemented by some hypothetical elements whose roles are determined by the degree of uncertainty in the particular building. The theme of creating digital replicas of the lost Ionic temples of Aegean Turkey has the potential of leading to the most resounding results. Creating, displaying, manipulating, archiving and sharing a digital representation of the form and appearance of a temple constitute one of the most challenging classes of Virtual Reality applications. In combination with immersive technologies, a virtual 3D visit to a temple site can become a very enticing way to study a temple or to experience its cultural site. 3D reconstruction models of these temples contain a wealth of information that can be analysed, tested and improved, because a digital 3D model is editable in both shape and appearance properties.

\section{ACKNOWLEDGEMENTS}

This research would not be possible without the generous grant of the British Council and permission and support of the British Museum, particularly Ian Jenkins and Peter Higgs of the Department of Greece and Rome.

\section{REFERENCES}

Akurgal, E., 2011. Ancient Civilizations and Ruins of Turkey, $11^{\text {th }}$. Ed., Net Turistik Yayınlar, San. Tic. A.Ş., ISBN 975-479$110-4$.

Apollonio, F. I, and Gaiani, M. and Sun, Z., 2013. 3D modelling and data enrichment in digital reconstructions of architectural heritage, International Archives of the Photogrammetry, Remote Sensing and Spatial Information Sciences, Volume XL-5/W2, 2013 XXIV International CIPA Symposium, Strasbourg, France.

Bammer, A., 1984. Das Heiligtum der Artemis von Ephesos, ADEVA, Austria, 3-201-01260-2.

Bingol, O., 2007. Magnesia on the Meander, Homer, ISBN 978-0500-05142-9.

Butler, H. C., 1922a. Sardis I, The Excavations, Part I, Leiden: E. J. Brill

Butler, H. C., 1922b. Sardis II, Architecture, Part I, The Temple of Artemis, Leiden: E. J. Brill.

Denker, A., 2017. Rebuilding Palmyra Virtually: Recreation of Its Former Glory in Digital Space, Virtual Archaeology Review Volume: 8, Issue: 17, pp. 20-30.
Dinsmoor, W. P., 1950. The Architecture of Ancient Greece, Revised $3^{\text {rd }}$ ed., B.T. Batsford Ltd.

Ferla, K. and Dontas, N. A., 2006. Priene, Hellenic Studies Series, $2^{\mathrm{n}}$ ed., Harvard University Press, ISBN: 9780674012721 .

Gruben, G., 2001. Griechische Tempel und Heiligtümer, $5^{\text {th }}$ ed., Munich.

Hahn, R., 2001. Anaximander and the Architects, State University of New York Press, ISBN 0-7914-4793-6.

Humann, Carl. 1904. Magnesia am Meander, Bericht über die Ergebnisse der Ausgrabungen, Berlin.

Jenkins, I., 2006. Greek Architecture and Its Sculpture, The British Museum Press, ISBN 978-0-7141-2240-3.

Matthews, H., 2014. Greco-Roman Cities of Aegean Turkey, Ege Yayinlari, ISBN 9786054701414.

Murray, A. S., 1904, A Catalogue of Sculpture in the Department of Greek and Roman Antiquities, British Museum V3, Kessinger Legacy Reprints, ISBN 9781164518495.

Pliny the Elder, Natural History, trans. Loeb Series. Cambridge: Harvard University Press.

Saldaña, M., 2015. "Cave and City: A Procedural

Reconstruction of the Urban Topography of Magnesia on the Maeander." PhD diss., University of California.

Spawforth, T., 2006. The Complete Greek Temples, Thames \& Hudson, ISBN: 9780500051429

Ozgunel, C., 2001. Smintheion, Troas'da Bir Kutsal Alan. Ankara

Trell, B. L., 1945. The Temple of Artemis at Ephesus, The American Numismatic Society, New York.

Alexander, T., Lefaivre, L. 1999. Classical Architecture: The Poetics of Order, The MIT Press, Cambridge, Massachusetts, $9^{\text {th }}$ Printing, ISBN 0-262-70031-X.

Brinkmann. V., and Schol, A. 2010. Bunte Götter: Die Farbigkeit antiker Skulptur, Katalog zur Ausstellung in Berlin, Pergamonmuseum.

Vitruvius, 1968. The Ten Books on Architecture, trans. M. H. Morgan, New York: Dover, 1968.

Wood, J. T., 1877. Discoveries at Ephesus, London.

Yegül, F., 2012. The temple of Artemis at Sardis, Dipteros und Pseudipteros Bauhistorische und Archaeologie Forschungen, Edited by Thekla Schulz. ISBN 978-605-5607-74-6, pp. 95111. 